\title{
Northern Margin of India in the Pre-Himalayan times
}

\author{
Vibhuti Rai* and Aradhana Singh \\ Centre of Advanced Study in Geology, University Of Lucknow, Lucknow 226007, UP, INDIA \\ * For correspondence, email: vibhutirai@gmail.com
}

The Himalayan orogeny, during the post-Mesozoic times, has critically altered the continental framework of Indian subcontinent. In fact, there have been complete destruction of the northern leading edge of the Greater India as most of it is either underthrust below the massive chain of mountains or have been detached along several of the northern dipping regional faults/thrusts (MBF, MCT and many others). Overthrusting of several of these portions has further complicated the scenario. The detachment of sedimentary pile from the basement and its subsequent overthrusting, besides detachment of basement rocks themselves and their obduction/thrusting, has aggravated the situation.

Several efforts to perceive the nature of this enigmatic northern edge of Indian subcontinent prior to collision of Indian continental block with the Asian block have resulted in conflicting data and confusing results. The geophysical efforts have also failed to decipher the true nature of the leading edge due to inconsistencies in profiles and difficulties in the interpretation. Most of the data remain conjectural, which are erroneously projected in excellent cartographical sections and neat diagrams. In fact, in many of these figures, massive exaggeration in the vertical scale have been included to emphasize the structural nature of the cross-section without incorporating any factual data.

At the outset, we would like to clarify that the hidden configuration of the domain of northern edge needs multi-faceted data such as geophysical, structural, tectonic, sedimentary basinal, geochronological and palaeontological in order to have an overall perception of the terrain. Since the northern edge was also laden with sedimentary sequences ranging from Palaeoproterozoic to Mesozoic time spans over an Archaean basement, these sedimentary sequences can provide the geotectonic domain in configuring the northern extent of the basin. The present contribution focuses on this aspect using the late Proterozoic to early Cambrian data from several of these basins.

In the post-Rodinia times, the disintegration of several Rodinian blocks assembled in a framework, which constituted the basis of a regional terrain called as Proto-Eastern Gondwana.
Although, the geomagnetic signatures vividly support this new assembly, the regional geotectonic framework authenticates the assembly to a larger extent.

The culmination of various fragments of Rodinia-derived blocks (continents) into Afro-Asian region supports the idea that a regional assembly of India (including Pakistan), Madagascar, Oman, Arabia, Afghanistan (Lut) and Iran juxtaposed each other in such a way that during the later part of Neoproterozoic, a large depositional basin developed near the equator. The basin evolved for almost 100 million years up to the end of Early Cambrian (including the Precambrian-Cambrian Boundary) and in a few areas, the deposition further continued.

The occurrence of large carbonate deposits alongside evaporites, followed by phosphogenic events provided crucial inputs in deciphering the depositional realm in a geotectonic framework. An assessment of the basin using palaeobiological evidences suggests that Varanger equivalent glaciation marked by diamictite, followed by a cap-carbonate, occurs as the marker of Ediacaran period and later in the stratigraphic sequence we get the Ediacaran biota, microfossils of cyanobacterial affinity, other algal fossils, acritarchs, calcareous algae, sponges, typical bedding plane traces (grazing) and small shelly fossils heralding the beginning of the Early Cambrian period.

The occurrence of phosphorite deposits, evaporites and the Terminal Proterozoic oil from the strata (named differently in different parts of the region) suggests regional depositional system in which marine phytoplanktons got deposited, accumulated and later matured to generate hydrocarbons (Heavy Oil) triggering the development of Ediacaran play in the region. In addition to the Proterozoic oil occurrences, huge limestone deposit provides major input to cement industry, which is currently required for resource development.

We propose here a geotectonic model comprising the palaeogeography and evolution of the late Proterozoic to early Cambrian basins that extended from Peninsular India right across present day Himalayan region with a note on the nature of the northern margin of the Indian subcontinent during this time-span. 